Article

\title{
Colonic Bacteria-Transformed Catechin Metabolite Response to Cytokine Production by Human Peripheral Blood Mononuclear Cells
}

\author{
Rajapandiyan Krishnamoorthy, Abdulraheem R. Adisa *(D), Vaiyapuri Subbarayan Periasamy, \\ Jegan Athinarayanan, Subash-Babu Pandurangan and Ali A. Alshatwi * \\ Nanobiotechnology and Molecular Biology Research Lab, Department of Food Science and Nutrition, College of \\ Food and Agriculture Sciences, King Saud University, Riyadh 11541, Saudi Arabia; \\ rkrishnamoorthy@ksu.edu.sa (R.K.); vsperrys@gmail.com (V.S.P.); jegan.dna@gmail.com (J.A.); \\ subashbabu80@gmail.com (S.-B.P.) \\ * Correspondence: rasheed.adisa@gmail.com (A.R.A.); alshatwi@ksu.edu.sa (A.A.A.); \\ Tel.: +966-543617783 (A.R.A.); +966-504236535 (A.A.A.)
}

Received: 5 September 2019; Accepted: 29 November 2019; Published: 5 December 2019

\begin{abstract}
Human gut microbes are a profitable tool for the modification of food compounds into biologically active metabolites. The biological properties of catechins have been extensively investigated. However, the bioavailability of catechin in human blood plasma is very low. This study aimed to determine the biotransformed catechin metabolites and their bioactive potentials for modulating the immune response of human peripheral blood mononuclear cells (PBMCs). Biotransformation of catechin was carried out using in-vitro gut microbial biotransformation method, the transformed metabolites were identified and confirmed by gas chromatography-mass spectrometry (GC-MS) and high-performance liquid chromatography-mass spectrometry (HPLC-MS). Present observations confirmed that the catechin was biotransformed into 11 metabolites upon microbial dehydroxylation and $C$ ring cleavage. Further, immunomodulatory potential of catechin metabolites was analyzed in peripheral blood mononuclear cells (PBMCs). We found up-regulation of anti-inflammatory cytokine (IL-4, IL-10) and down-regulation of pro-inflammatory (IL-16, IL-12B) cytokine may be due to Th2 immune response. In conclusion, biotransformed catechin metabolites enhance anti-inflammatory cytokines which is beneficial for overcoming inflammatory disorders.
\end{abstract}

Keywords: anti-inflammatory; cytokine; immunomodulation; human peripheral blood mononuclear cells; catechin; metabolites; proliferation; antioxidants

\section{Introduction}

Human health is directly influenced by the immune system, which is designed to provide the host protection against harmful foreign substances. Almost all infectious diseases are the result of an inadequate immune response [1]. Therefore, the modulation of the immune system is of great importance for the control of many immunological disorders. Green tea has been consumed for centuries due to its health benefits [2]. Green tea extract contains different polyphenols, such as catechin (C), epicatechin (EC), epigallocatechin gallate (EGCG), and epicatechin gallate (ECG), that are responsible for various health benefits, such as antioxidant, antibacterial, and anticancer properties, and protection against cardiovascular diseases, among others [3]. A number of studies have demonstrated that catechin is poorly absorbed and is excreted to a small extent in urine $[4,5]$. Subsequently, the fate and bioavailability of catechin, including intestinal absorption, distribution in human tissue, and excretion, must be established. 
The gut microbiota transforms the phytocompounds into numerous bioactive metabolites. Recent studies have suggested that catechin can be degraded and/or modified by many intestinal bacteria [6], thus significantly altering the parent compound [7]. In recent decades, studies have focused on catechin biotransformation by the microorganisms present in the human gut. Despite this exponential increase in microbiome research, the link between biotransformation and the role of biotransformed metabolites still remains largely unexplored. Recently, reports have suggested that biotransformed catechin metabolites exert several biological activities, such as the inhibition of platelet aggregation and the activation function, the inhibition of cyclooxgenous- 2 in colon cancer cells, and antiproliferative activity in prostate and cancer cells [8,9].

Low-grade chronic inflammatory processes result from the interaction between monocytes, $\mathrm{T}$ lymphocytes, endothelial cells, and smooth muscle cells [10]. Predominantly, subsets of monocytes and T lymphocytes play a critical role in immunoregulation. Several studies have highlighted the immunomodulatory effects of biotransformed or bio-active metabolites on proinflammatory and anti-inflammatory cytokine production in different in vivo and in vitro models. Several studies have reported that polyphenol-related gut bio-active metabolites modulate the immune response through the stimulation of certain anti-inflammatory cytokines and decreased proinflammatory cytokine production [11-13]. The human gastrointestinal tract contains high level of biotransformed metabolites, which can penetrate host tissues and interact with immune cells, thereby triggering host immunological response [14]. However, no reports are available on the biotransformed catechin and how it responds to anti-inflammatory cytokines (Interleukins-IL-1A, IL-1B, IL-4, IL-5, IL-6, IL-10, IL-13, transforming growth factor beta (TGF- $\beta$ ) and pro-inflammatory cytokines (IL-2, IL-12, IL-17A, interferon gamma (INF $\gamma$ ), granulocyte-macrophage colony-stimulating factor (GM-CSF), tumor necrosis factor alpha (TNF- $\alpha$ ).

The gut microbe produces a larger toolkit of enzymes that catalyze the diverse range of chemical reactions and results in transformation of catechin. However, this alteration can cause increase or decrease the activity on human health [15]. The aim of the present study was to investigate in vitro microbial biotransformation and the effect of biotransformed metabolites on the proliferation of human peripheral blood mononuclear cells (PBMCs), specifically the production of pro-inflammatory cytokines and anti-inflammatory cytokine profiles such as IL-2, IL-4, IL-5, IL-6, IL-10, IL-12, IL-13, IL-17A, interferon gamma (IFN- $\gamma$ ), transforming growth factor- $\beta$, (TGF- $\beta$ ), tumor necrosis factor- $\beta$ (TNF- $\beta$ ), and GM-CSF. The expression of genes related to human PBMCs was also studied.

\section{Materials and Methods}

\subsection{Reagents}

3-(4,5-dimethylthiazol-2-yl)-2,5-diphenyltetrazolium bromide (MTT) and Histopaque were purchased from Sigma (St. Louis, MO, USA) and RPMI-1640 medium was obtained from Invitrogen (Grand Island, NY, USA). Multianalyte ELISA array kits for 12 cytokines were purchased from Qiagen (MEH004A, Qiagen, Hilden, Germany). Distilled water was obtained using a Milli-Q system (Millipore Laboratory, Bedford, MA, USA). Deionized water was obtained using a Direct-QUV 3 Multipore Water purification system (Millipore, Burlington, MA, USA). All other chemicals and reagents were of analytical grade unless otherwise specified.

\subsection{Preparation of Fecal Slurry}

Fecal samples were obtained from three healthy volunteers who had usually taken a normal diet and had not received any antibiotics for a minimum of six months prior to stool collection. All subjects gave their informed consent for inclusion before they participated in the study. The study was conducted in accordance with the Declaration of Helsinki, and the protocol was approved by the Institutional Review Board of King Saud University College of Medicine (E-19-3703). Fecal bacterial suspensions were prepared by the method described previously [16]. Briefly, the collected fresh 
samples were stored in $4{ }^{\circ} \mathrm{C}$ in to an anaerobic chamber and diluted $(1: 10 w / v)$ with $0.1 \mathrm{M}$ phosphate buffer ( $\mathrm{pH}$ 7.2) within 1-2 h and mixed uniformly by vortexing. The resultant fecal slurries were pooled, slurry was centrifuged at $4000 \times g$ for $10 \mathrm{~min}$, and resultant fecal bacterial suspension inoculated into fermentation vessels containing minimal medium.

\subsection{Fecal Batch-Culture Fermentation}

Fecal batch-culture fermentation was carried out as previously reported [17]. Briefly, five separate 500-mL glass fermenter vessels were filled with $250 \mathrm{~mL}$ of sterilized medium (peptone bacteriological $(2 \mathrm{~g} / \mathrm{L}), \mathrm{NaCl}(0.1 \mathrm{~g} / \mathrm{L})$, yeast extract $(2 \mathrm{~g} / \mathrm{L}), \mathrm{K}_{2} \mathrm{HPO}_{4}(0.04 \mathrm{~g} / \mathrm{L}), \mathrm{KH}_{2} \mathrm{PO}_{4}(0.04 \mathrm{~g} / \mathrm{L})$, resazurin $(1 \mathrm{mg} / \mathrm{L})$, $\mathrm{MgSO}_{4} \cdot 7 \mathrm{H}_{2} \mathrm{O}(0.01 \mathrm{~g} / \mathrm{L}), \mathrm{NaHCO}_{3}(2 \mathrm{~g} / \mathrm{L}), \mathrm{CaCl}_{2} \cdot 6 \mathrm{H}_{2} \mathrm{O}(0.01 \mathrm{~g} / \mathrm{L})$, hemin $(50 \mathrm{mg} / \mathrm{L})$, Tween 80 (2 mL/L), vitamin $\mathrm{K}(10 \mu \mathrm{L} / \mathrm{L})$, bile salts $(0.5 \mathrm{~g} / \mathrm{L})$, L-cysteine $(0.5 \mathrm{~g} / \mathrm{L})$, and double-distilled water. The medium was regulated to a $\mathrm{pH}$ of 7.0 and constantly sparged with $\mathrm{O}_{2}$-free $\mathrm{N}_{2}$ overnight. The $\mathrm{pH}$ was maintained at 7.0 and the temperature at $37^{\circ} \mathrm{C}$, so as to simulate the conditions of the human gut. The vessels were inoculated separately with $15 \mathrm{~mL}$ of fecal slurry $(1.5 \%$ w/v) along with $100 \mathrm{mM}$ catechin (C0567, Sigma-Aldrich). A negative control was maintained in a separate batch-culture vessel prepared under the same conditions without catechin. Anaerobic conditions were maintained and biotransformed metabolites harvested at $24 \mathrm{~h}$, then immediately stored at $-80^{\circ} \mathrm{C}$ for further analysis.

\subsection{Separation and Purification of Biotransformed Metabolites}

The biotransformed metabolites were separated by the method described in Takagaki and Nanjo [18] with some modifications. The entire crude culture samples were centrifuged at $7000 \times g$ for $10 \mathrm{~min}$ at $10{ }^{\circ} \mathrm{C}$. The resulting supernatants were collected and filtered using a $0.25-\mu \mathrm{m}$ Millipore microfilter. The collected filtrates were extracted three times with an equivalent volume of ethyl acetate. Excess solvents from biotransformed crude extract (BCE) were removed by roto-evaporator under controlled temperature $\left(40{ }^{\circ} \mathrm{C}\right)$. Further, the BCE were subjected to preparative thin layer chromatography using mobile phase $0.5 \%(v / v)$ acetic acid in $60 \%(v / v)$ aqueous methanol. Two visible spots were observed, these procedures were repeated $\approx 50$ times and the respective spots were pooled separately in order to obtain the compounds quantitatively. The separated compounds were named as biotransformed metabolites A (BTMFA) and biotransformed metabolites B (BTMFB), and all were pooled, filtered using a PVDF 0.22- $\mu \mathrm{m}$ microfilter and further profiled by gas chromatography and mass spectrometry (GC-MS) and high-performance liquid chromatography/mass spectrometry (HPLC-MS).

\subsection{GC-MS Analysis}

The pooled fecal samples, control (fecal sample along with medium without catechin) and separated biotransformed metabolites were analyzed by GC-MS using the modified method [19] with a ZB-5MS $30 \mathrm{~m} \times 0.25$ i.d. $\times 0.25 \mu \mathrm{m}$ capillary column (Phenomenex, Cheshire, UK) with an injection volume of $10 \mu \mathrm{L}$, an initial temperature of $70{ }^{\circ} \mathrm{C}$ for $10 \mathrm{~min}$, which was increased to $150{ }^{\circ} \mathrm{C}$ at $10{ }^{\circ} \mathrm{C} / \mathrm{min}$ for $15 \mathrm{~min}$ and then to $220^{\circ} \mathrm{C}$ at $5^{\circ} \mathrm{C} / \mathrm{min}$ for $15 \mathrm{~min}$, an injector temperature of $270{ }^{\circ} \mathrm{C}$, an MS transmission line of $280^{\circ} \mathrm{C}$, an ion source at $190^{\circ} \mathrm{C}$, and a split ratio of 1:100. Scanning of mass was carried out at $50-650 \mathrm{~m} / \mathrm{z}$ at $0.82 \mathrm{scans} / \mathrm{s}$. The electron impact energy was $70 \mathrm{eV}$. Biotransformed compounds were identified in relation to their retention time, with the mass spectra of authentic standards from the NIST 98 library.

\subsection{HPLC-MS Analysis}

HPLC were performed using Agilent 1290 infinity system (Agilent Technologies Inc, Waldbronn, Gremany) coupled with quadrupole LC/MS Agilent 6120 (Agilent Technologies Inc). The samples were injected on to a C-18 column $(4.625 \mathrm{~cm}, 51 \mathrm{~m}$; phenomenex, Torrance, CA, USA). The solvent used were $\mathrm{A}-90 \%$ acetic acid-water and $\mathrm{B}-10 \% \mathrm{MeOH}$, establishing following elution gradient; isocratic $10 \%$ B for $5 \mathrm{~min}, 10-100 \%$ B over $10 \mathrm{~min}, 100 \%$ B for $6 \mathrm{~min}$, and re-equilibration of the column using 
flow rate of $0.1 \mathrm{~mL} / \mathrm{min}$. The spectra were recorded in negative and positive ionization mode between $m / z 50$ and 1200 .

\subsection{Immunomodulatory Activity of Biotransformed Metabolites on PBMCs}

One hundred milliliters $(100 \mathrm{~mL})$ of venous blood was collected from a single healthy donor who had not consumed any antioxidant-containing foods (e.g., salads, fruits, and natural/manufactured juices) $24 \mathrm{~h}$ prior to blood collection. PBMCs were isolated using Histopaque (Histopaque-1077, Sigma) density gradient methods by centrifuging for $15 \mathrm{~min}$ at $2500 \times g$ [20] with some modifications. The concentration of PBMCs was adjusted to $1 \times 10^{4}$ cells $/ \mathrm{mL}$ in RPMI-1640 culture medium. The cells were maintained in RPMI-1640 culture medium supplemented with $10 \% \mathrm{FBS}$ at $37^{\circ} \mathrm{C}$ and $5 \% \mathrm{CO}_{2}$ in a humid environment for $24 \mathrm{~h}$.

\subsection{Cytotoxicity (MTT) Assay}

The MTT assay was used to examine cell viability. Briefly, the isolated primary PBMCs (lymphocytes, monocytes) were seeded at a density of $1 \times 10^{4}$ cells/mL in 96-well plates. The pooled biotransformed metabolites, BTMFA and BTMFB, and BCE were treated with different doses $(0,20,40,60,80$ and $100 \mu \mathrm{g} / \mathrm{mL})$. After 24 and $48 \mathrm{~h}$ incubation, $20 \mu \mathrm{L}(\mathrm{MTT}, 5 \mathrm{mg} / \mathrm{mL}) \mathrm{of}$ 3-(4,5-dimethyl-2-thiazolyl)-2,5-diphenyl-2H-tetrazolium bromide were added to each well. The plates were incubated for $4 \mathrm{~h}$ to overnight, and the supernatant was then removed by centrifugation. The insoluble formazan was dissolved with dimethyl sulfoxide (DMSO 100\%) and the optical density was measured at $570 \mathrm{~nm}$ and reference filter $(630 \mathrm{~nm})$ using a microplate reader (Promega, Madison, WI, USA). From the values obtained, the percentage viability (relative to survival of control cells) was calculated. Each assay was performed three times (in duplicate/dose) and data are presented as the percentage mean \pm SD.

\subsection{Cytokines Analysis}

BTMFA, BTMFB, and BCE were tested for their effect on the production of pro-inflammatory and anti-inflammatory cytokines in unstimulated PBMCs. The metabolites were dissolved in DMSO and further diluted in RPMI-1640 cell culture medium. The final concentration of DMSO in the cells was less than $0.1 \%$. In the control experiments, this concentration did not show any effects on the measured parameters. PBMCs were added $\left(1 \times 10^{4}\right.$ cells/mL) to 96 -well plates and pre-incubated for $1 \mathrm{~h}$ at $37^{\circ} \mathrm{C}$ in a humidified environment containing $5 \% \mathrm{CO}_{2}$. After treatment, the supernatants were collected after centrifugation and stored at $-80{ }^{\circ} \mathrm{C}$ until further analysis. The level of cytokines was determined by using two multi-analyte ELISArray kits (Qiagen, Hilden, Germany) (pro-inflammatory cytokines IL-2, IL-12, IFN- $\gamma$, GM-CSF, and TNF- $\alpha$, and anti-inflammatory cytokines IL-4, IL-5, IL-10, IL-13, IL-17A, and TGF- $\beta 1$ ) according to the manufacturer's protocol. Briefly, $50 \mu \mathrm{L}$ of assay buffer were added to each well of ELISArray plate and then $50 \mu \mathrm{l}$ collected test samples and control samples were added to appropriate well and incubated for $2 \mathrm{~h}$ at $37^{\circ} \mathrm{C}$. The unbounded cytokines were removed and $100 \mu \mathrm{L}$ of detection antibody solution were added to each well and incubated for $1 \mathrm{~h}$ and wells were washed three times with washing solution and $100 \mu \mathrm{L}$ of Avidin-HRP (Qiagen) was added to each well and incubated for $30 \mathrm{~min}$. After washing, developmental followed by stop solution were added to each well at respective intervals. Finally, the level of cytokines was detected at $450 \mathrm{~nm}$ using a microplate reader (Promega).

\subsection{Quantitative Reverse Transcription-Polymerase Chain Reaction (qRT-PCR)}

Complementary DNA (cDNA) was synthesized directly from treated and untreated human WBC using FastLane Cell cDNA Kit (Qiagen, Hilden, Germany). The purity was checked and quantified using the NanoDrop spectrophotometer ND-1000 (NanoDrop Technologies Inc., Wilmington, DE, USA). Quantitative real-time PCR was performed with the SYBR Green PCR Master Mix (Qiagen, Chatsworth, CA, USA) in an ABI 7500 fast real-time PCR system (Applied Biosystems, Foster City, 
CA, USA) according to the manufacturer's protocol. The mRNA levels of IL-4, IL-10, IL-12B, IL-16, and the reference gene, glyceraldehyde 3-phosphate dehydrogenase (GAPDH), were assayed using gene-specific SYBR Green-based QuantiTect ${ }^{\circledR}$ Primer Assays (Qiagen, Hilden, Germany) according to manufacturer's instructions. A $25-\mu \mathrm{L}$ reaction volume was used in each well of the PCR plates. Briefly, $12.5 \mu \mathrm{L}$ of master mix, $2 \mu \mathrm{L}$ of assay primer and $2 \mu \mathrm{L}$ of template cDNA (500 pg) were added to each well. Reaction mixtures were incubated for initial denaturation at $95^{\circ} \mathrm{C}$ for $5 \mathrm{~min}$, followed by $40 \mathrm{PCR}$ cycles. Each cycle consisted of $95^{\circ} \mathrm{C}$ for $5 \mathrm{~s}$ and $60^{\circ} \mathrm{C}$ for $30 \mathrm{~s}$. The relative quantification of the aforementioned gene expression was analyzed using an ABI 7500 Fast Real-Time PCR system (Applied Biosystems). The values were expressed as fold changes over the control and expressed as means with their standard errors.

\subsection{Statistical Analysis}

Data were analyzed using ANOVA (SPSS/11.5 software package, IBM Corporation, Armonk, CA, USA) followed by Tukey's test. All data are expressed as mean \pm standard error of the mean (SEM). Differences were considered to be significant if the $p$-value was $\leq 0.05$.

\section{Results and Discussion}

\subsection{Profiling of Biotransformed Metabolites}

The metabolites present in BTMFA and BTMFB were profiled by GC/MS (Figures 1 and 2). A total of 11 (10 metabolites from BTMFA and 1 metabolite from BTMFB) biotransformed catechin metabolites were identified. BTMFA consisted of the following simple form phenolic metabolites: dehydroquinic acid (1), 4-ethylphenol (2), 4-methoxyphenyl propan-2-ol (3), 3-phenyl propionic acid (4), 2-phenoxyethanol (5), benzene tricarboxylic acid,1,2-dimethyl ester (6), catechol-1,4-benzenediol (7), benzene-1,3,5-tris1-methylpropyl (8), 3,5,7-trihydroxy-2H-chromen-2-one (9), and 4-hydroxyphenylpropionic acid (10). BTMFB were rich in dimethoxycinnamic acid (B1). The presence of all the metabolites were confirmed by HPLC-MS analysis based on $\mathrm{m} / \mathrm{z}$. The obtained data were listed in the Supplementary File 1. None of the metabolites/ precursor were found in the control GC/MS analysis (Supplementary Table S2). The literature confirms that the compounds obtained were phenolic metabolites and are beneficial to human health [21,22].

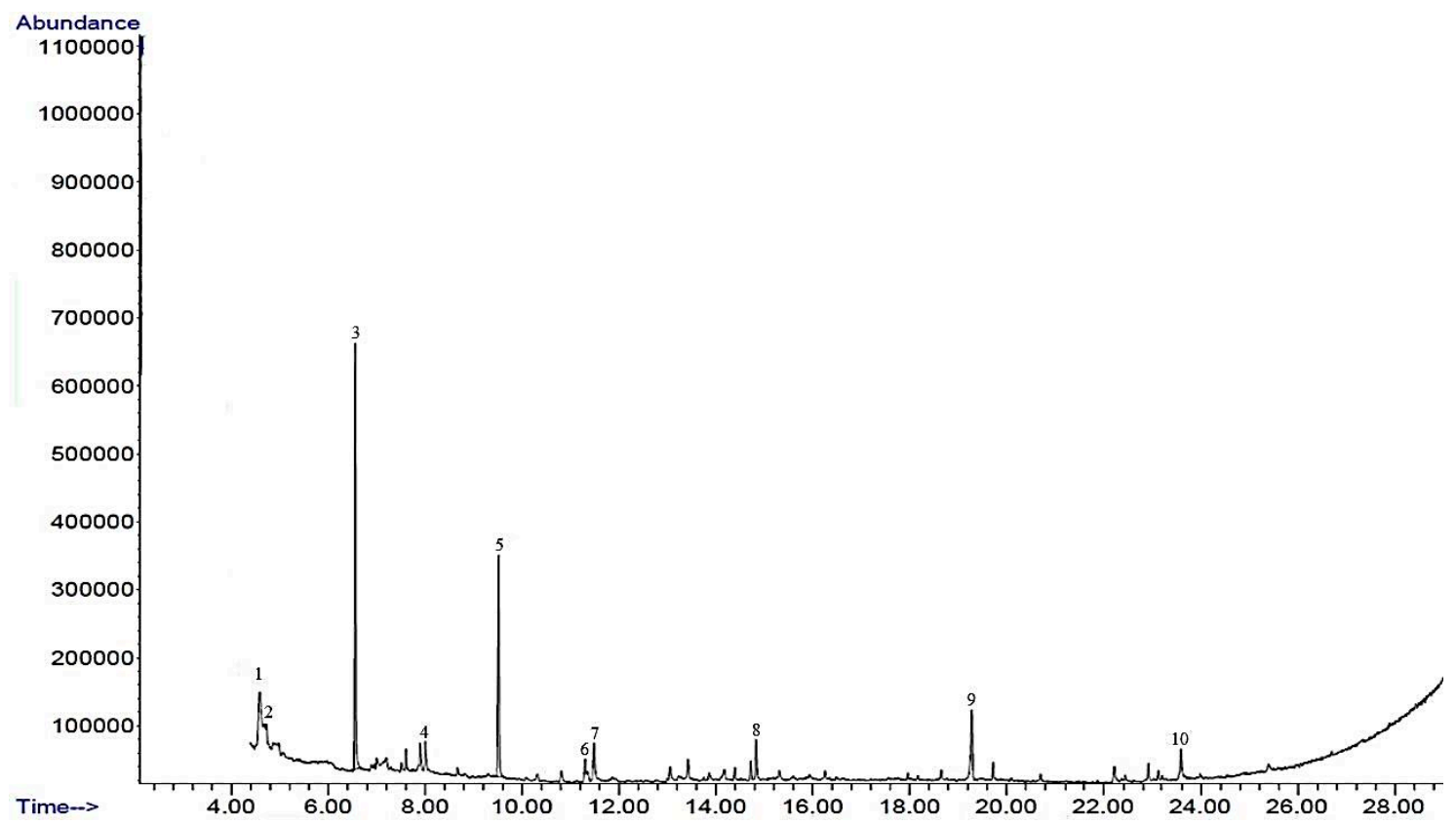

Figure 1. Biotransformed metabolite A (BTMFA). 


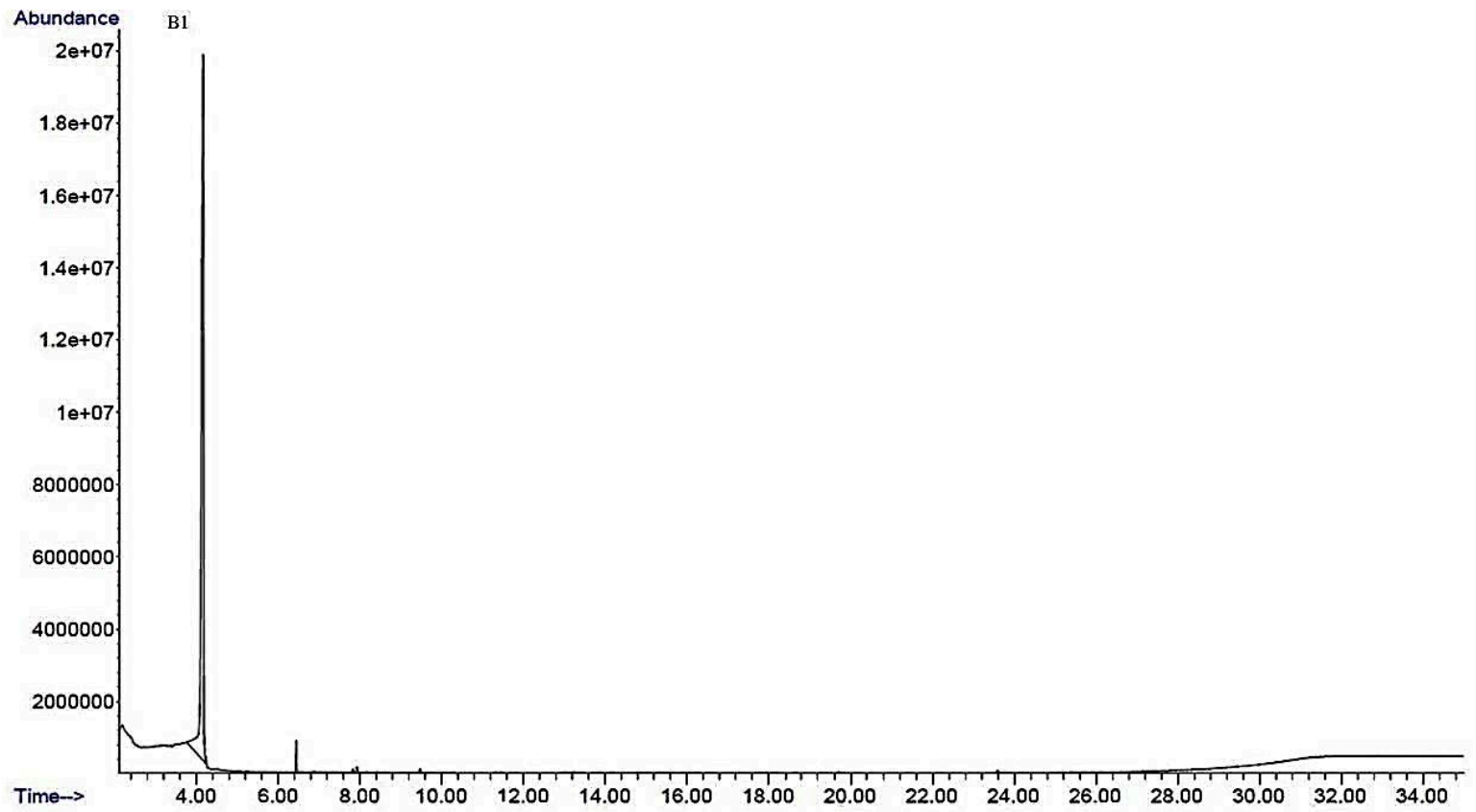

Figure 2. Biotransformed metabolite B (BTMFB).

Gas chromatography-mass spectrophotometry (GC-MS) profiles of catechin biotransformed metabolites by human gut microbes.

The catechin structure has the potential to strongly interact with bacterial enzymes due to its benzenoid ring and the hydrogen bonding potential of its hydroxyl groups [23,24]. Several isoflavone metabolizing gut bacteria such as Eggerthella lenta, Flavonifractor plautii, Adlercreutzia equolifaciens, Asaccharobacter celatus, Slackia equolifaciens, and Slackia isoflavoniconvertensare are capable of transforming catechin in the intestinal tract as a result of dehydroxylation and C-ring cleavage to form metabolites 7, 10 and B1 [6]. Lactobacillus is capable of reducing catechin by inducible enzymes under in vitro anaerobic conditions to produce metabolites 1, 4, 6, and B1 [25]. The metabolites 2, 3, 4, 7, 10 and B1 were identified as the major catechin metabolites in human blood plasma and urine samples collected from participants 6-48 h after drinking tea [19]. The consumption of catechins by humans results in an increase of metabolite 4 in the blood plasma [26] and an increased urine excretion of metabolites 1, 3, 4, 10 and B1 [27,28]. In vivo animal studies have shown similar results in terms of urinary metabolites from rats after feeding with a catechin diet [29]. These metabolites were also found in an in vitro experiment as a major product of colonic metabolism of polyphenols by human fecal microbiota [30].

\subsection{Effect of Biotransformed Catechin Metabolites on the Cell Population of Human PBMCs}

A number of studies on the role of polyphenols in PBMC proliferation, differentiation, and activation for the regulation and determination of immune function are available [21]. In recent years, research on the biotransformation of polyphenols has shed some light on biotransformed polyphenols in response to immune function. In the present study we evaluated the immunomodulatory effect of biotransformed catechin metabolites. BTMFA, BTMFB, and BCE from catechin and their effects on the cell population of PBMCs (monocytes, T lymphocytes, and B lymphocytes) were investigated by MTT analysis. We measured the viability of cell culture medium alone and biotransformed metabolites at varying concentrations $(20,40,60,80$, and $100 \mu \mathrm{g} / \mathrm{mL})$. PBMC viability in culture medium alone was in the range of $99-100 \%$, BTMFA treatment in the range of $90-100 \%$ viability (Figure 3(A1-A3)), and BTMFB treated in the range of $84-86 \%$ viability after $48 \mathrm{~h}$ (Figure 3(B1-B3)). Pure catechin treatment with PBMC revealed the decreasing cell viability of unstimulated PBMCs [31,32]. Similarly, other studies have also reported that $\mathrm{T}$ cell proliferation was inhibited by catechin through inhibiting $\mathrm{T}$ cell division and cell cycle progression in a dose-dependent manner in vitro [33]. Surprisingly, our 
results showed that biotransformed catechin metabolites did not induce cell death. The cytotoxic effect of pure catechin and alterations in biotransformed catechin may due to the addition and alteration of hydroxyl groups [34,35]. Moreover, the BCE of biotransformed metabolites showed slight and significant proliferation in unstimulated PBMCs in a dose-dependent manner. This may be due to the presence of high concentrations of various bacterial metabolites, which may act as mitogen for the proliferation of PBMCs. Recent studies have confirmed that polyphenol metabolites are able to penetrate tissue and also permeate into macrophages to be further converted into the methylated form [36].
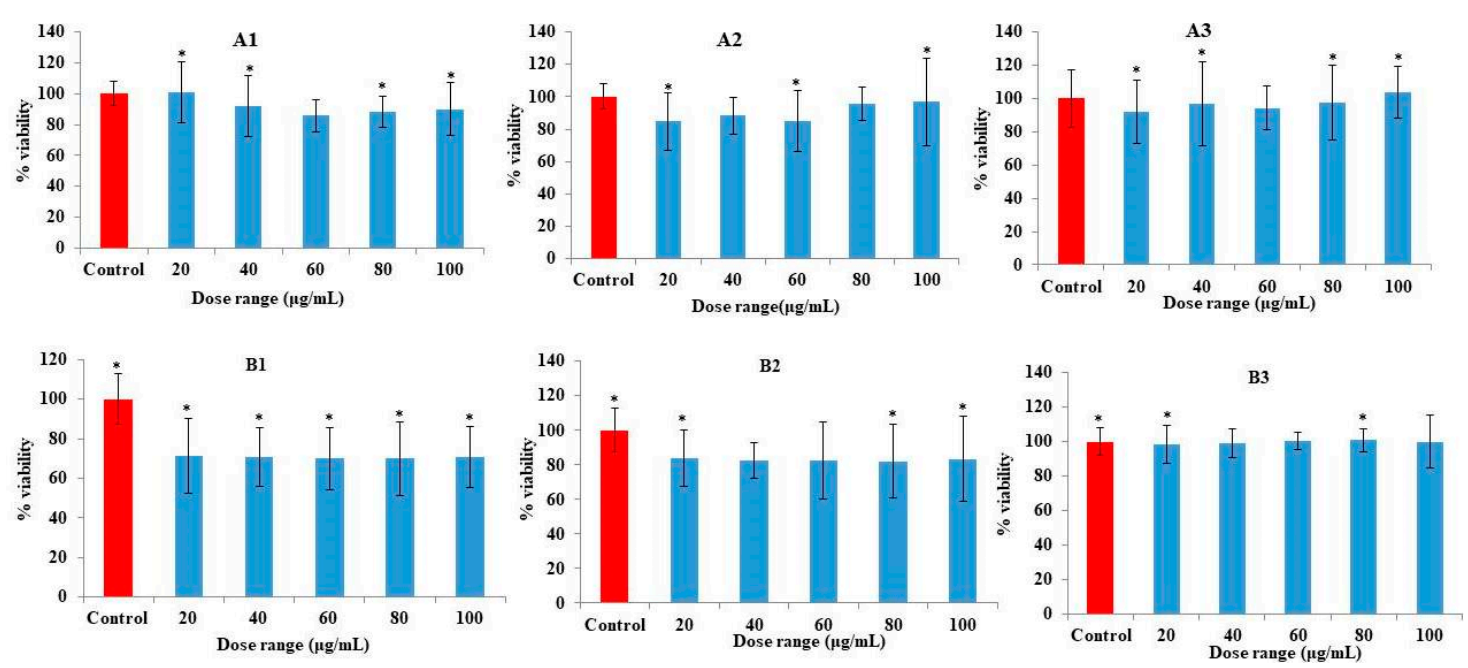

Figure 3. Effects of biotransformed catechin metabolites on the viability of non-stimulated human peripheral blood mononuclear cells (PBMCs) by MTT assay-24 h, (A) (A1)—BTMFA, (A2)—BTMFB, (A3)—BCE, and 48 h. (B), (B1)—BTMFA, (B2)—BTMFB, (B3)—BCE. Cells were treated with metabolites at concentration of $20,40,60,80$, and $100 \mu \mathrm{g} / \mathrm{mL}$. The columns represent the mean \pm standard error of the mean (SEM) of the data from duplicate tests. Asterisk $\left(^{*}\right)$ represents data statistically significantly different with respect to the control $(p<0.05)$.

\subsection{Effect of Biotransformed Metabolites on Cytokine Secretion in PBMCS}

Cytokines are modulators of inflammation and play a key role in acute and chronic inflammation via a complex network of interactions. The influence of catechin biotransformed metabolites on the release of 12 cytokines in unstimulated PBMCs are shown in Figure 4. PBMC incubation with BTMFA increased the production of IL-6 (174.89 pg/mL), IL-8 (68.19 pg/mL), IL-1B (52.55 pg/mL), IL-1A $(31.05 \mathrm{pg} / \mathrm{mL}), \mathrm{IL}-10(30.57 \mathrm{pg} / \mathrm{mL})$ and IL-2 $(12.75 \mathrm{pg} / \mathrm{mL})$. However, BTMFB and BCE produced similar quantity of IL-6 $(10.36 ; 10.89 \mathrm{pg} / \mathrm{mL})$ compared to unstimulated control (IL-6, $7.49 \mathrm{pg} / \mathrm{mL}$ ). The secretion of IL-4, IL-12, IL-17A, IFN- $\gamma$, TNF- $\alpha$, and GM-CSF were suppressed and IL-8 levels were similar in all the tested colonic bacteria-transformed catechin metabolites. In previous studies, epicatechin (EC), epicatechin gallate (ECG), epigallocatechin (EGC) and epigallocatechin gallate (EGCG) were reported to inhibit the production of IL-1A, IL-1B, and IL-6, but increased the levels of IFN- $\gamma$, TNF- $\alpha$, and GM-CSF $[37,38]$. This obtained data suggests that catechin is transformed into many metabolites by colonic bacteria and these metabolites stimulate human PBMCs differently. Our results indicate that cytokine secretion by PBMCs due to the stimulation of colonic catechin metabolites was dependent on structure, such as monomeric flavanols. The superior effect of BTMFA due to presence of hydroxylated phenolic acid and the length of the side chains of the functional groups present in the metabolites influence the cytokine families [9]. The transformed metabolites that are present in BTMFA such as phenyl propionic acid, benzene carboxylic acid, cinnamic acid and catechol are capable of stimulating human PBMCS to produce inflammatory cytokines [14,39]. The results of IL-1B and IL-6 were in agreement with other studies performed with monomeric and dimeric flavanols of phenolic acids [10]. It was also reported that the simple form of phenolic derivates, such as flavones and flavanols, inhibit 
TNF- $\alpha$ secretion in macrophages [40]. Phenolic metabolites derived from gut microbial metabolisms modulate the inhibitory or stimulatory activity of PBMCs for cytokine production and may result from transcriptional and post-transcriptional events, which activate a series of cytokines.

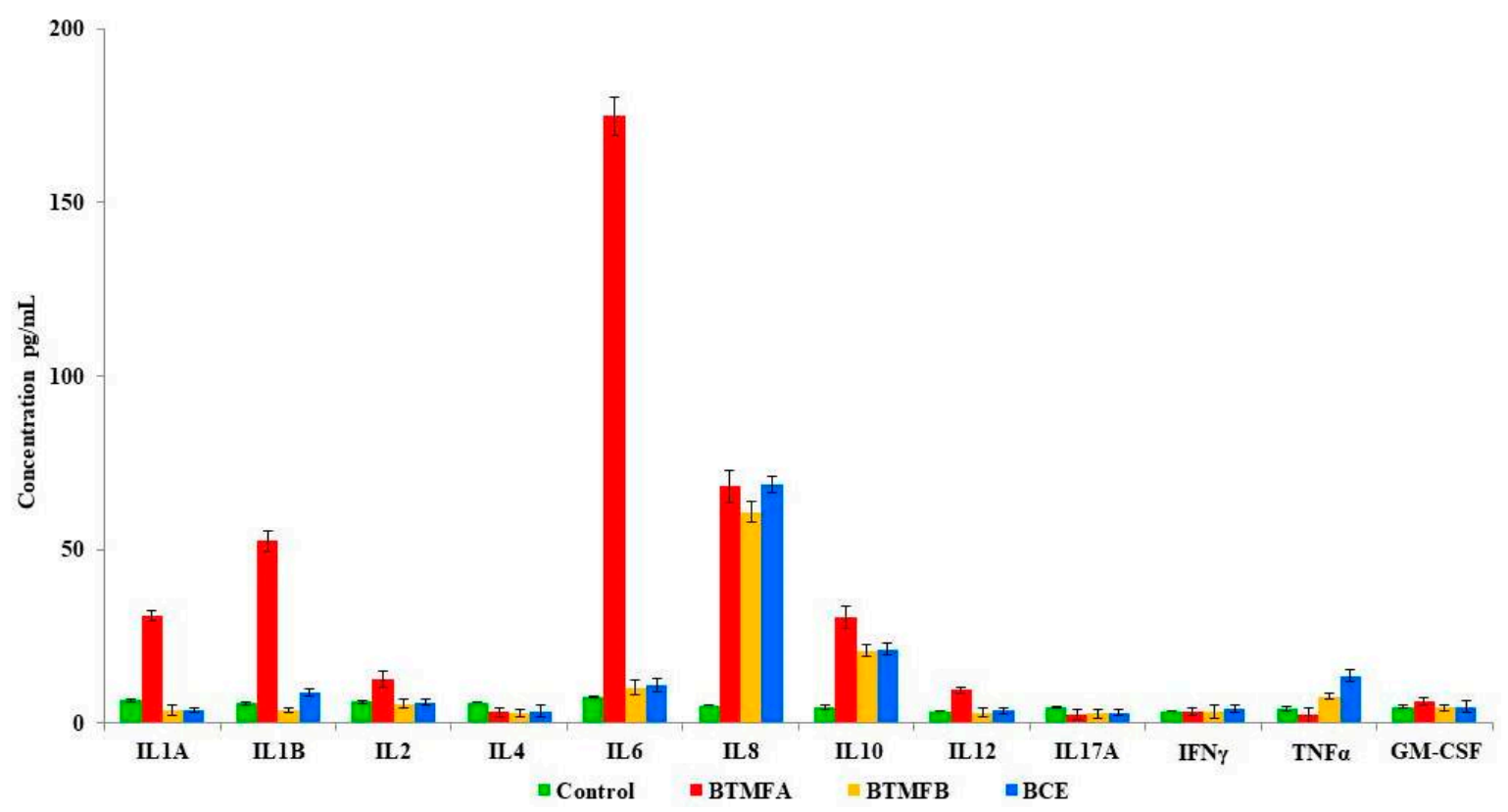

Figure 4. Response of biotransformed catechin metabolites BTMFA, BTMFB, and BCE on release of interleukin (IL)-2, IL-4, IL-5, IL-10, IL-12, IL-13, IL-17A, granulocyte-macrophage colony stimulating factor (GM-CSF), interferon gamma (IFN- $\gamma$ ), transforming growth factor-beta (TGF- $\beta 1$ ), and tumor necrosis factor (TNF- $\alpha$ ) were measured in PBMCs (duplicates).

\subsection{Effect of Biotransformed Metabolites on the Expression of IL mRNA in PBMCs}

The roles of biotransformed catechin metabolites on the gene expression of cytokines such as IL-4, IL-10, IL-12B, and IL-16 in PBMCs were analyzed (Figure 5). After exposure of BTMFA, BTMFB, and $\mathrm{BCE}$, the gene expression of the target genes were analyzed. Dose-dependent upregulation was observed in IL-4, IL-10 and IL12-B genes of BTMFA-treated PBMCs. BTFA trigger Th2 cells to produce IL-4, IL-6, IL-10 cytokines and thereby regulate the humoral immunity. In other studies catechin and quercetin induce the production and gene expression of Th1 cytokines and down-regulated the Th2 derived cytokines [41]. The expression was 3-fold higher in IL-4, IL-10, and IL-16 in high dose BCE-treated cells due to the higher affinity binding of the receptors in immune cells, thus triggering an intracellular signaling pathway that ultimately regulated the host's immune response [42]. IL-4, IL-12B, and IL-16 gene expression was downregulated when BTMFB concentration increased. Th2 cells produce IL-4 [43] and play a role in the production of allergen specific IgE, tissue migration of Th2 cells, regulation of tight junctions, and epithelial barrier integrity [44,45]. The downregulation of these genes, which regulate T cells through AhR mediated pathways [46], resulted in the suppression of SP1 protein expression and apoptotic cell death in many cancer cells [47]. Moreover, dihydroxy phenolic metabolites induce the activation of mitogen-activated protein kinase (MAPK) and nuclear factor (NF-kB) pathways, resulting in the activation of dendric cells and regulatory $\mathrm{T}$ cells, which contribute to the maintenance of immunotolerance, therefore inhibiting autoimmunity [48]. IL-10 regulates inflammatory interleukin production and antibody response [49]. IL-12B activates the antitumor activity of macrophages and promotes the cytolytic activity of natural killer (NK) cells and lymphokine activated killer cells [50]. IL-16 mediates its biological activity through CD4 and promotes Th1 mediated responses [51]. Th1 cells can inhibit cancer cells by inducing cytotoxic activity in NK cells [52]. NK cells produce perforin and granzyme B which triggers apoptosis and necrosis in cancer cells by 
creating a hole in the cell membrane, thus facilitating cell destruction [53]. Results clearly suggest that biotransformed catechin metabolites showed immunomodulatory effects in human PBMCs.
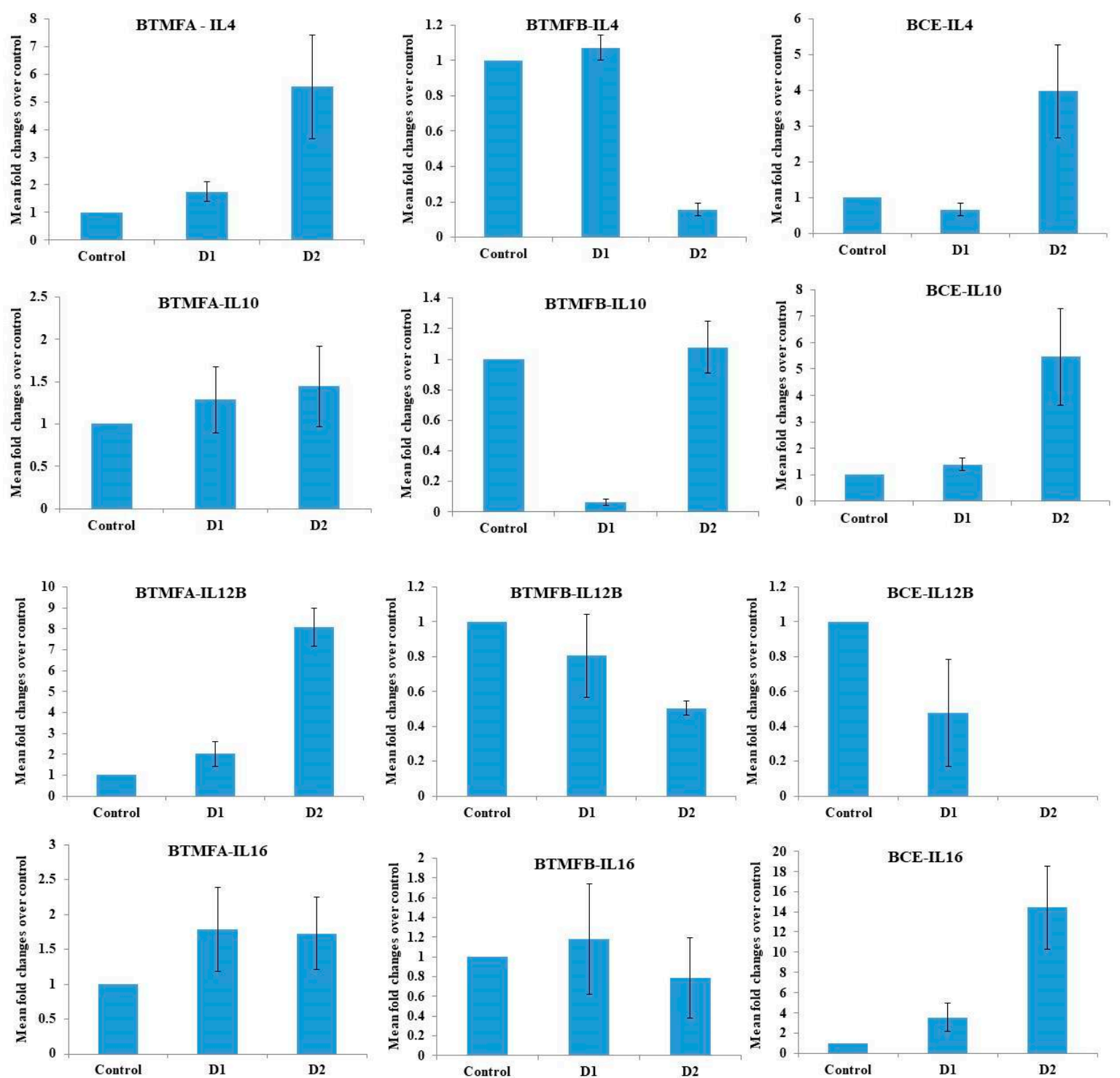

Figure 5. Quantitative reverse transcription-polymerase chain reaction (RT-PCR) analysis of gene expression in human PBMCs. Comparison of change in expression level, shown as fold change after exposure to BTMFA, BTMFB, and BCE for $24 \mathrm{~h}$. Data represent the mean \pm SD of three determinations. D1-150 $\mu \mathrm{g} / \mathrm{mL}, \mathrm{D} 2-300 \mu \mathrm{g} / \mathrm{mL}$.

\section{Conclusions}

The results in the present study revealed that gut microbes transform catechin by dehydroxylation and $C$ ring cleavage. The biotransformed catechin metabolites stimulate human PBMCs differently. BTMFA and BCE upregulate the production of anti-inflammatory cytokines and downregulate pro-inflammatory cytokines. We conclude that biotransformed catechin metabolites enhance Th2 immune response by anti-inflammatory cytokines, which is more beneficial to overcome inflammatory disorders. Further studies on the use of gut microbe-derived pure catechin metabolites as immunomodulatory agents should be carried out.

Supplementary Materials: The following are available online at http://www.mdpi.com/2218-273X/9/12/830/s1, Figure S1: HPLC-MS chromatographic profile of BTMFA; Figure S2: HPLC-MS chromatographic profile of 
BTMFB; Table S1: The detected metabolites exact masses and observed m/z values in HPLC-MS; Figure S3: GCMS chromatographic profile of pooled fecal slurry; Table S2: GCMS analysis metabolites detected in the pooled fecal slurry.

Author Contributions: Conceptualization, R.K. and V.S.P.; methodology, A.R.A. and R.K.; formal analysis, J.A. and S.-B.P.; investigation, R.K. and A.A.A.; resources, A.A.A.; writing-original draft preparation, R.K. and A.R.A.; writing—review and editing, A.A.A. and R.K.; supervision, A.A.A.; project administration, V.S.P.; funding acquisition, A.A.A.

Funding: The authors would like to thank Deanship of scientific research for funding and supporting this research through the initiative of DSR Graduate Students Research Support (GSR). Also, we thank the Deanship of Scientific Research and RSSU at King Saud University for their technical support.

Conflicts of Interest: The authors declare no conflict of interest.

\section{References}

1. Nii-Trebi, N.I. Emerging and Neglected Infectious Diseases: Insights, Advances, and Challenges. BioMed Res. Int. 2017, 4, 1-15. [CrossRef]

2. Baba, S.; Osakabe, N.; Natsume, M.; Muto, Y.; Takizawa, T.; Terao, J. In Vivo Comparison of the Bioavailability of (+)-Catechin, (-)-Epicatechin and Their Mixture in Orally Administered Rats. J. Nutr. 2011, 131, 2885-2891. [CrossRef] [PubMed]

3. Frei, B.; Higdon, J.V. Antioxidant activity of tea polyphenols in vivo: Evidence from animal studies. J. Nutr. 2003, 133, 3275S-3284S. [CrossRef] [PubMed]

4. Thilakarathna, S.; Rupasinghe, H. Flavonoid Bioavailability and Attempts for Bioavailability Enhancement. Nutrients 2013, 5, 3367-3387. [CrossRef] [PubMed]

5. Clifford, M.N. Diet-Derived Phenols in Plasma and Tissues and their Implications for Health. Planta Med. 2004, 70, 1103-1114. [CrossRef] [PubMed]

6. Takagaki, A.; Nanjo, F. Biotransformation of (-)-epicatechin, (+)-epicatechin, (-)catechin, and (+)-catechin by intestinal bacteria involved in isoflavone metabolism. Biosci. Biotechnol. Biochem. 2016, 80, 199-202. [CrossRef]

7. Rechner, A.R.; Kroner, C. Anthocyanins and colonic metabolites of dietary polyphenols inhibit platelet function. Thromb. Res. 2005, 116, 327-334. [CrossRef]

8. Kim, Y.H.; Won, Y.; Yang, X.; Kumazoe, M.; Yamashita, S.; Hara, A.; Takagaki, A.; Goto, K.; Nanjo, F.; Tachibana, H. Green Tea Catechin Metabolites Exert Immunoregulatory Effects on CD4+ T Cell and Natural Killer Cell Activities. J. Agric. Food Chem. 2016, 64, 3591-3597. [CrossRef]

9. Gao, K.; Xu, A.; Krul, C.; Venema, K.; Liu, Y.; Niu, Y.; Lu, J.; Bensoussan, L.; Seeram, N.P.; Heber, D.; et al. Of the Major Phenolic Acids Formed during Human Microbial Fermentation of Tea, Citrus, and Soy Flavonoid Supplements, Only 3,4-Dihydroxyphenylacetic Acid Has Antiproliferative Activity. J. Nutr. 2006, 136, 52-57. [CrossRef]

10. Tedgui, A.; Mallat, Z. Cytokines in atherosclerosis: Pathogenic and regulatory pathways. Physiol. Rev. 2006, 86, 515-581. [CrossRef]

11. Contreras, T.C.; Ricciardi, E.; Cremonini, E.; Oteiza, P.I. (-)-Epicatechin in the prevention of tumor necrosis alpha-induced loss of Caco-2 cell barrier integrity. Arch. Biochem. Biophys. 2015, 573, 84-91. [CrossRef] [PubMed]

12. Kook, S.H.; Choi, K.C.; Cho, S.W.; Cho, H.K.; Lee, K.D.; Lee, J.C. Catechin-7-O- $\beta$-D-glucopyranoside isolated from the seed of Phaseolus calcaratus Roxburgh ameliorates experimental colitis in rats. Int. Immunopharmacol. 2015, 29, 521-527. [CrossRef] [PubMed]

13. Porath, D.; Riegger, C.; Drewe, J.; Schwager, J. Epigallocatechin-3-gallate impairs chemokine production in human colon epithelial cell lines. J. Pharmacol. Exp. Ther. 2005, 315, 1172-1180. [CrossRef] [PubMed]

14. Leyva-López, N.; Gutierrez-Grijalva, E.P.; Ambriz-Perez, D.L.; Heredia, J.B. Flavonoids as Cytokine Modulators: A Possible Therapy for Inflammation-Related Diseases. Int. J. Mol. Sci. 2016, 17, 921. [CrossRef] [PubMed]

15. Guthrie, L.; Wolfson, S.; Kelly, L. The human gut chemical landscape predicts microbe-mediated biotransformation of foods and drugs. eLife 2019, 8, e42866. [CrossRef] [PubMed] 
16. O'Donnell, M.M.; Rea, M.C.; O'Sullivan, Ã.; Flynn, C.; Jones, B.; McQuaid, A.; Shanahan, F.; Ross, R.P. Preparation of a standardised faecal slurry for ex-vivo microbiota studies which reduces inter-individual donor bias. J. Microbiol. Methods 2016, 129, 109-116. [CrossRef]

17. Tzounis, X.; Vulevic, J.; Kuhnle, G.G.; George, T.; Leonczak, J.; Gibson, G.R.; Spencer, J.P. Flavanol monomer-induced changes to the human faecal microflora. Br. J. Nutr. 2007, 99, 782-792. [CrossRef]

18. Takagaki, A.; Nanjo, F. Catabolism of (+)-Catechin and (-)-Epicatechin by Rat Intestinal Microbiota. J. Agric. Food Chem. 2013, 61, 4927-4935. [CrossRef]

19. Roowi, S.; Stalmach, A.; Mullen, W.; Lean, M.E.; Edwards, C.A.; Crozier, A. Green Tea Flavan-3-ols: Colonic Degradation and Urinary Excretion of Catabolites by Humans. J. Agric. Food Chem. 2010, 58, 1296-1304. [CrossRef]

20. Carrie, E.P.; Steven, M.W.; Allen, C.E. Isolation of Subsets of Immune Cells. Methods Mol. Biol. 2005, 302, 95-115.

21. Cuevas, A.; Saavedra, N.; Salazar, L.A.; Abdalla, D.S. Modulation of immune function by polyphenols: Possible contribution of epigenetic factors. Nutrients 2013, 5, 2314-2332. [CrossRef] [PubMed]

22. Conti, B.J.; Búfalo, M.C.; Golim, M.D.A.; Bankova, V.; Sforcin, J.M. Cinnamic Acid Is Partially Involved in Propolis Immunomodulatory Action on Human Monocytes. Evid. Based Complementary Altern. Med. 2013, 2013, 109864. [CrossRef] [PubMed]

23. David, M.P.; Patrícia, V.; José, A.P.; Paula, B.A. Phenolics: From Chemistry to Biology. Molecules 2009, 14, 2202-2211.

24. Parr, A.J.; Bolwell, J.P. Phenols in the plant and in man. The potential for possible nutritional enhancement of the diet by modifying the phenols content or profile. J. Sci. Food Agric. 2002, 80, 985-1012. [CrossRef]

25. Rodríguez, H.; Curiel, J.A.; Landete, J.M.; De las Rivas, B.; De Felipe, F.L.; Gómez-Cordovés, C.; Muñoz, R. Food phenolics and lactic acid bacteria. Int. J. Food Microbiol. 2009, 132, 79-90. [CrossRef] [PubMed]

26. Das, N.P. Studies on flavonoid metabolism: Absorption and metabolism of (+)-catechin in man. Biochem. Pharmacol. 1971, 20, 3435-3445. [CrossRef]

27. Ward, N.C.; Croft, K.D.; Puddey, I.B.; Hodgson, J.M. Supplementation with grape seed polyphenols results in increased urinary excretion of 3-hydroxyphenylpropionic acid, an important metabolite of proanthocyanidins in humans. J. Agric. Food Chem. 2004, 52, 5545-5549. [CrossRef] [PubMed]

28. Rios, L.Y.; Gonthier, M.P.; Rémésy, C.; Mila, I.; Lapierre, C.; Lazarus, S.A.; Williamson, G.; Scalbert, A. Chocolate intake increases urinary excretion of polyphenol-derived phenolic acids in healthy human subjects. Am. J. Clin. Nutr. 2003, 77, 912-918. [CrossRef]

29. Gonthier, M.P.; Remesy, C.; Scalbert, A.; Cheynier, V.; Souquet, J.M.; Poutanen, K.; Aura, A.M. Microbial metabolism of caffeic acid and its esters chlorogenic and caftaric acids by human faecal microbiota in vitro. Biomed. Pharmacother. 2006, 60, 536-540. [CrossRef]

30. Sánchez-Patán, F.; Cueva, C.; Monagas, M.; Walton, G.E.; Gibson, G.R.; Martín-Álvarez, P.J.; Victoria Moreno-Arribas, M.; Bartolomé, B. Gut microbial catabolism of grape seed flavan-3-ols by human faecal microbiota. Targeted analysis of precursor compounds, intermediate metabolites andend-products. Food Chem. 2012, 131, 337-347. [CrossRef]

31. Sipahi, H.; Gostner, J.M.; Becker, K.; Charehsaz, M.; Kirmizibekmez, H.; Schennach, H.; Aydin, A.; Fuchs, D. Bioactivities of two common polyphenolic compounds: Verbascoside and catechin. Pharm. Biol. 2015, 54, 712-719. [CrossRef] [PubMed]

32. Saleh, F.; Raghupathy, R.; Asfar, S.; Oteifa, M.; Al-Saleh, N. Analysis of the effect of the active compound of green tea (EGCG) on the proliferation of peripheral blood mononuclear cells. BMC Complementary Altern. Med. 2014, 14, 322. [CrossRef] [PubMed]

33. Wu, D.; Guo, Z.; Ren, Z.; Guo, W.; Meydani, S.N. Green tea EGCG suppresses T cell proliferation through impairment of IL-2/IL-2 receptor signaling. Free Radic. Biol. Med. 2009, 47, 636-643. [CrossRef] [PubMed]

34. Joray, M.B.; Trucco, L.D.; González, M.L.; Napal, G.N.; Palacios, S.M.; Bocco, J.L.; Carpinella, M.C. Antibacterial and Cytotoxic Activity of Compounds Isolated from Flourensia oolepis. Evid. Based Complementary Altern. Med. 2015, 21,1-11. [CrossRef]

35. Li, F.; Awale, S.; Tezuka, Y.; Kadota, S. Cytotoxic constituents from Brazilian red propolis and their structure-activity relationship. Bioorg. Med. Chem. 2008, 16, 5434-5440. [CrossRef] [PubMed] 
36. Kawai, Y.; Nishikawa, T.; Shiba, Y.; Saito, S.; Murota, K.; Shibata, N.; Kobayashi, M.; Kanayama, M.; Uchida, K.; Terao, J. Macrophage as a target of quercetin glucuronides in human atherosclerotic arteries: Implication in the anti-atherosclerotic mechanism of dietary flavonoids. J. Biol. Chem. 2008, 283, 9424-9434. [CrossRef]

37. Neyestani, T.R.; Gharavi, A.; Kalayi, A. Selective effects of tea extract and its phenolic compounds on human peripheral blood mononuclear cell cytokine secretions. Int. J. Food Sci. Nutr. 2009, 60, 79-88. [CrossRef]

38. Crouvezier, S.; Powell, B.; Keir, D.; Yaqoob, P. The effects of phenolic components of Tea on the production of pro- and anti-inflammatory cytokines by human leukocytes in vitro. Cytokine 2001, 13, 280-286. [CrossRef]

39. Schirmer, M.; Smeekens, S.P.; Vlamakis, H.; Jaeger, M.; Oosting, M.; Franzosa, E.A.; ter Horst, R.; Jansen, T.; Jacobs, L.; Bonder, M.J. Linking the human gut microbiome to inflammatory cytokine production capacity. Cell 2016, 167, 1125-1136. [CrossRef]

40. Wang, J.; Mazza, G. Effects of anthocyanins and other phenolic compounds on the production of tumour necrosis factor alpha in LPS/IFN-gamma-activated RAW 264.7 macrophages. J. Agric. Food Chem. 2002, 50, 4183-4189. [CrossRef]

41. Nair, M.P.; Kandaswami, C.; Mahajan, S.; Chadha, K.C.; Chawda, R.; Nair, H.; Schwartz, S.A. The flavonoid, quercetin, differentially regulates Th-1 (IFNgamma) and Th-2 (IL4) cytokine gene expression by normal peripheral blood mononuclear cells. Biochim. Biophys. Acta 2002, 1593, 29-36. [CrossRef]

42. Ding, S.; Jiang, H.; Fang, J. Regulation of Immune Function by Polyphenols. J. Immunol. Res. 2018, 3, 1-8. [CrossRef] [PubMed]

43. Akdis, M. Healthy immune response to allergens: T regulatory cells and more. Curr. Opin. Immunol. 2006, 18, 738-744. [CrossRef] [PubMed]

44. Seltmann, J.; Roesner, L.M.; von Hesler, F.W.; Wittmann, M.; Werfel, T. IL-33 impacts on the skin barrier by downregulating the expression of filaggrin. J. Allergy Clin. Immunol. 2015, 135, 1659-1661. [CrossRef] [PubMed]

45. Soyka, M.B.; Wawrzyniak, P.; Eiwegger, T.; Holzmann, D.; Treis, A.; Wanke, K.; Kast, J.I.; Akdis, C.A. Defective epithelial barrier in chronic rhinosinusitis: The regulation of tight junctions by IFN-gamma and IL-4. J. Allergy Clin. Immunol. 2012, 130, 1087-1096. [CrossRef] [PubMed]

46. Terao, J.; Murota, K.; Kawai, Y. Conjugated quercetin glucuronides as bioactive metabolites and precursors of aglycone in vivo. Food Funct. 2011, 2, 11-17. [CrossRef]

47. Li, L.; Davie, J.R. The role of Sp1 and Sp3 in normal and cancer cell biology. Ann. Anat. 2010, 192, $275-283$. [CrossRef]

48. Luo, X.; Yu, X.; Liu, S.; Deng, Q.; Liu, X.; Peng, S.; Li, H.; Liu, J.; Cao, Y. The role of targeting kinase activity by natural products in cancer chemoprevention and chemotherapy (Review). Oncol. Rep. 2015, 34, 547-554. [CrossRef]

49. Engelhardt, K.R.; Shah, N.; Faizura-Yeop, I.; Kocacik Uygun, D.F.; Frede, N.; Muise, A.M.; Shteyer, E.; Filiz, S.; Chee, R.; Elawad, M.; et al. Clinical outcome in IL-10- and IL-10 receptor-deficient patients with or without hematopoietic stem cell transplantation. J. Allergy Clin. Immunol. 2013, 131, 825-830. [CrossRef]

50. Hsieh, C.S.; Macatonia, S.E.; Tripp, C.S.; Wolf, S.F.; O'Garra, A.; Murphy, K.M. Development of TH1 CD41 T cells through IL-12 produced by Listeria-induced macrophages. Science 1993, 260, 547-549. [CrossRef]

51. Richmond, J.; Tuzova, M.; Cruikshank, W.; Center, D. Regulation of cellular processes by interleukin-16 in homeostasis and cancer. J. Cell Physiol. 2014, 229, 139-147. [CrossRef] [PubMed]

52. Haabeth, O.A.; Kristina, B.L.; Clara, H.; Ian, M.D.; Guttorm, H.; Bjarne, B.; Alexandre, C. Inflammation driven by tumour-specific Th1 cells protects against B-cell cancer. Nat. Commun. 2011, 2, 240. [CrossRef] [PubMed]

53. Mellor-Heineke, S.; Villanueva, J.; Jordan, M.B.; Marsh, R.; Zhang, K.; Bleesing, J.J.; Filipovich, A.H.; Risma, K.A. Elevated Granzyme B in Cytotoxic Lymphocytes is a Signature of Immune Activation in Hemophagocytic Lymphohistiocytosis. Front. Immunol. 2013, 4, 72. [CrossRef] [PubMed]

(C) 2019 by the authors. Licensee MDPI, Basel, Switzerland. This article is an open access article distributed under the terms and conditions of the Creative Commons Attribution (CC BY) license (http://creativecommons.org/licenses/by/4.0/). 